\title{
ANALISIS PRODUKSI DAN EFISIENSI BERAS
}

\author{
Dede Ruslan \\ Indra Maipita \\ Fakultas Ekonomi Universitas Negeri Medan \\ Sumatera Utara, Indonesia \\ email: $\underline{\text { dras_ruslan@yahoo.com ; imaipita@gmail.com }}$
}

\begin{abstract}
The purpose of this study to find out if the factors of production could give contribution tu the production or income and the cost of rice production, the economy efficiensy of rice production. It is hoped thet the result of this study could give information to farmers and local government in Deli Serdang about the contributions of the factors of production to the production or income and the cost of rice farm opration production. From the study, it is shown that the characteristic of model of production, the using of the factors of production and teh cost of production opportunity is increasing returns to scale or decreasing cost industries. The economy scale of rice production describes that the estimate cost of corn farm production. The analysis of economy efficiensy from the rice production was taken form condition that the produtions marginal cost is lower than the corn scale. From the contributions of field, seed, fertilizer and labor toward the rice production, it can be explained that rice production can be raised by increasing the field, seed, fertilizer, and labor usings.
\end{abstract}

Keywords: Rice Production, Rise Cost Production, Efficiensy of rice production

\section{PENDAHULUAN}

$D$ enyediaan pangan, terutama beras, dalam jumlah yang cukup dan harga terjangkau tetap menjadi prioritas utama pembangunan nasional. Selain merupakan makanan pokok untuk lebih dari 95\% rakyat Indonesia, Padi juga telah menyediakan lapangan kerja bagi sekitar 20 juta rumah tangga petani di pedesaan.

Deli Serdang merupakan sentra pertanian di Sumatera Utara yang memiliki luas lahan pertanian 90,234 hektar atau 36,27\% dari luas daerah Deli Serdang yang tercatat 249.772 hektar. Berbagai program yang di

QE Journal | Vol.03 - No.04 December 2014 - 230 
laksanakan Pemerintah Daerah menjadikan Deli Serdang lumbung pangan Sumatera Utara yang menghasilkan padi 290.516 ton sehingga surplus 32.130 ton. Kabupaten Deli Serdang merupakan salah satu daerah di Provinsi Sumatera Utara yang memiliki potensi cukup besar dalam bidang pertanian. Daerah dengan luas 249.772 hektar ini memiliki potensi lahan pertanian seluas 243.957 hektar. Ini artinya, daerah yang memiliki 22 kecamatan serta 380 desa dan 14 kelurahan ini, semuanya terdapat lahan pertanian. Sedangkan lahan khusus terkait persawahan/ladang untuk tanaman padi saat ini sudah mencapai 90.601 ha atau $36,27 \%$ dari luas lahan di Kabupaten Deli Serdang, dimana lahan sawah irigasi seluas 25.002 ha, lahan sawah non irigasi seluas 19.365 ha dan lahan kering ladang/huma seluas 46.234 ha.

Permasalahan klasik sistem pertanian pada umumnya adalah keterbatasan modal petani dalam mengembangkan usahataninya. Demikian juga usahatani beras, dibutuhkan sejumlah modal selama budidaya, mulai dari sewa lahan, pembersihan lahan, bibit, tenaga kerja, pupuk, obat-obatan, pemeliharaan dan panen. Besar kecilnya modal yang didapat disediakan oleh petani mempengaruhi luas lahan usahatani beras yang dikelola. Selain masalah ketersediaan modal, usahatani beras yang dilakukan, pengelolaannya belum optimal. Oleh sebab itu permasalahan umum dalam produksi beras adalah efisiensi usahatani yang dapat memberi keuntungan kepada petani. Efisiensi usahatani beras tersebut pada akhirnya akan mempengaruhi investasi beras dalam budidaya beras.

Upaya peningkatan produksi beras dapat dilakukan melalui peningkatan penggunaan teknologi produksi dan perluasan areal tanam. Penggunaan teknologi baik berupa pemupukan, obat-obatan, bibit varitas unggul maupun perluasan areal tanam akan mempercepat swasembada beras. Pertanyaan penting sehubungan dengan sentra produksi beras Kabupaten Deli Serdang adalah Apakah usahatani beras di Deli serdang efisien dan menguntungkan bagi petani ? Jawaban terhadap pertanyaan ini memerlukan kajian ilmiah karena Deli serdang sebagai lumbung beras di Sumatera Utara. Sehubungan dengan masalah pokok di atas, penulis tertarik untuk menganalisis efisiensi usahatani beras di Kabupaten Deli Serdang, dengan masalahnya adalah : Bagaimana kontribusi faktor-faktor produksi terhadap produksi atau pendapatan usahatani beras di Deli Serdang serta Bagaimana kontribusi faktor-faktor biaya input produksi 
terhadap total biaya produksi usahatani beras di Deli Serdang dan berdasarkan kontribusi faktor-faktor produksi terhadap produksi atau pendapatan dan biaya produksi usahatani beras, apakah usahatani beras di Deli Serdang efisien?

\section{Konsep Efisiensi}

Efisiensi usahatani beras ditentukan oleh faktor produksi dan teknologi budidaya. Faktor-faktor produksi usahatani beras terdiri dari lahan, bibit, pupuk, obat-obatan dan tenaga kerja. Teknologi budidaya terdiri dari pembibitan, persiapan lahan, penanaman, dan pemeliharaan. Faktor-faktor produksi dan teknologi budidaya akan menentukan besar kecilnya produksi atau pendapatan dan biaya produksi. Selisih antara produksi atau pendapatan dengan biaya produksi merupakan keuntungan sebagai ukuran efisiensi usaha tani beras.

Kombinasi antara faktor-faktor produksi dan teknologi budidaya beras akan menentukan seberapa besar produksi atau pendapatan usahatani beras. Sebaliknya biaya produksi usahatani beras sangat tergantung pada kondisi pasar faktor-faktor produksi dan teknologi budidaya beras. Petani pada umumnya tidak dapat mengendalikan harga faktor-faktor produksi, harga teknologi budidaya dan harga produksi beras. Petani pada umumnya dapat mengendalikan penggunaan faktor-faktor produksi dan teknologi budidaya beras atau petani pada umumnya dapat mengendalikan produksi beras. Oleh sebab itu petani beras diasumsikan sebagai pengikut harga atau price taker terhadap harga faktor-faktor produksi, harga teknologi budidaya dan harga produksi beras.

Asumsi pengikut harga atau price taker bagi petani beras mengakibatkan tujuan usahatani beras bukan laba maksimal tetapi biaya minimal. Pada kondisi biaya minimal dari usahatani beras dan harga produksi, harga faktor-faktor produksi dan harga teknologi budidaya tertentu, petani akan memperoleh laba maksimal. Dengan kata lain, usahatani beras dengan biaya minimal juga berarti laba maksimal atau usahatani beras dengan laba maksimal juga berarti biaya minimal (Varian, 1993). Dalam analisis efisiensi usahatani beras berikut ini, tujuan petani adalah meminimalkan biaya produksi pada tingkat harga produksi, harga faktor-faktor produksi dan harga teknologi tertentu. Analisis efisiensi usahatani beras bukan dalam arti fisik tetapi efisiensi ekonomi. 
Fungsi produksi beras merupakan teknologi proses produksi dengan kombinasi teknologi budidaya (pembibitan, persiapan lahan, penanaman, pemeliharaan) dengan faktor-faktor produksi (lahan, bibit, pupuk, obatobatan, dan tenaga kerja). Spesifikasi fungsi produksi usahatani beras diasumsikan mengikuti fungsi produksi Cobb-Douglas. Karena sifat-sifat penting dari fungsi produksi Cobb-Douglas adalah tingkat substitusi marginal semakin kecil dan deminishing returns dari faktor-faktor produksi dan teknologi budidaya beras. Produksi beras menggunakan berbagai varitas faktor-faktor produksi, sehingga fungsi produksi Cobb-Douglas dirumuskan dalam bentuk difusi teknologi (Spence, 1976; Dixit and Stiglitz, 1977; Ehtier, 1982; Romer, 1986: 1990), yaitu:

$$
Q_{j}=A L_{J}{ }^{1-\alpha} \sum_{j=1}^{\text {Nom }} F_{j}{ }^{\alpha}
$$

dimana:

$\mathrm{Q}_{\mathrm{j}}=$ kuantitas produk beras,

$\mathrm{A}=$ parameter produktivitas dari teknologi budidaya beras,

$\mathrm{L}_{\mathrm{j}}=$ kuantitas tenaga kerja usahatani beras,

Nom $=$ varitas faktor-faktor produksi beras,

$\mathrm{F}_{\mathrm{j}}=$ kuantitas faktor produksi ke-j,

$\mathrm{j}=1,2, \ldots, \mathrm{N}$, dan

$0<\alpha<1$.

Parameter (A) menjelaskan peranan teknologi budidaya beras dan kebijakan pemerintah dalam usahatani beras, seperti subsidi pupuk dan parameter kebijakan pemerintah lainnya terhadap produktivitas. Parameter (A) juga merupakan tingkat adopsi teknologi, khususnya adopsi teknologi budidaya beras. Tenaga kerja $\left(\mathrm{L}_{j}\right)$ merupakan ukuran jumlah tenaga kerja yang digunakan pada usahatani beras. Menurut Dixit and Stiglitz (1977), parameter tenaga kerja juga menjelaskan skala ekonomis. Sifat penjumlahan secara terpisah dari faktor produksi $\left(\mathrm{F}_{\mathrm{j}}\right)$ menjelaskan bahwa produk marginal dari faktor produksi ke-j adalah independen dari jumlah faktor produksi ke-j. Jika (NOM) merupakan tipe atau varitas faktor produksi usahatani beras yang tersedia dengan harga tertentu maka petani beras termotivasi menggunakan semua faktor produksi. Penggunaan semua faktor produksi akan menghasilkan keseimbangan $F_{j}=F_{j}$, sehingga fungsi produksi (2.1) berubah menjadi:

QE Journal | Vol.03 - No.04 December 2014 - 233 


$$
Q_{j}=A L_{j}{ }^{1-\alpha}\left(N O M F_{j}\right)^{\alpha} N O M^{1-\alpha}
$$

Biaya produksi daru usahatani beras merupakan penjumlah biaya teknolgoi budidaya dan biaya faktor-faktor produksi, yaitu:

$$
C_{j}=F C+W \times L_{j}+P F B \times\left(N O M \times F_{j}\right)
$$

dimana:

$\mathrm{Cj}=$ biaya usahatani beras,

FC = biaya tetap dari teknologi budidaya,

$\mathrm{W}=$ tingkat upah atau pendapatan tenaga kerja, dan

$\mathrm{PFB}=$ harga-harga faktor produksi.

Sebagaimana dijelaskan di atas, tujuan dari usahatani beras adalah minimasi biaya produksi pada tingkat produksi beras tertentu. Untuk meminimasi biaya produksi maka fungsi biaya produksi dalam bentuk fungsi lagrange (Chiang and Wainwright, 2005), yaitu:

$$
\begin{aligned}
C_{j}=F C+ & W \times L_{j}+P F B \times\left(N O M \times F_{j}\right) \\
& +\lambda\left[Q_{j}-A L_{j}{ }^{1-\alpha}\left(N O M \times F_{j}\right)^{\alpha} N O M^{1-\alpha}\right]
\end{aligned}
$$

dimana parameter $[\lambda]$ merupakan pengganda lagrangian, yaitu sebagai ukuran perubahan biaya produksi akibat perubahan produksi.

Kondisi biaya minimal dari usahatani beras memerlukan dua syarat, yaitu syarat perlu atau necessary condition dan syarat cukup atau sufficient condition. Akan tetapi bentuk concavity dari fungsi produksi Cobb-Douglas akan menjamin biaya minimal (Chiang and Wainwright, 2005), sehingga penyelidikan biaya minimal hanya dengan menggunakan syarat perlu atau necessary condition. Syarat perlu dari biaya minimal (2.4) adalah

$$
\begin{aligned}
& \frac{\partial C j}{\partial L j}=W-\left[(1-\alpha) A L^{-\alpha}(N O M \times F j)^{\alpha} N O M{ }^{1-\alpha}\right] \lambda=0 \\
& \frac{\partial C j}{\partial F j}=P F B \times N O M-\left[\alpha A L^{1-\alpha}{ }^{1-\alpha}{ }^{\alpha-1} N O M\right] \lambda=0
\end{aligned}
$$

Dari (2.5A) dan (2.5B) diperoleh keseimbangan parameter $[\lambda]$ sehingga kondisi optimal penggunaan faktor-faktor produksi adalah: 


$$
\begin{aligned}
& \frac{(1-\alpha) A L j^{-\alpha}(N O M \times F j)^{\alpha} N^{1-\alpha}}{W}=\frac{\alpha A L j^{1-\alpha} F j^{\alpha-1}}{P F B} \\
& \frac{(1-\alpha) N O M \times F j}{W}=\frac{\alpha L j}{P F B} \\
& L j=\frac{(1-\alpha) P F B \times N O M \times F j}{\alpha W}
\end{aligned}
$$

Persamaan (2.6) disebut garis ekspansi produksi, yaitu kombinasi antara tenaga kerja (LUJ) dengan berbagai faktor-faktor produksi lainnya pada kondisi biaya minimal (Pindyck and Rubinfeld, 1995).

Substitusi (2.6) ke (2.2) akan menghasilkan penggunaan optimal dari berbagai faktor produksi, yaitu:

$$
\begin{aligned}
& Q j=A\left[\frac{(1-a) P F B \times N O M \times F j}{\alpha W}\right]^{1-\alpha}(N O M F j)^{\alpha} N O M^{1-\alpha} \\
& Q j=A\left[\frac{1-\alpha}{\alpha}\right]^{1-\alpha}\left[\frac{P F B}{W}\right]^{1-\alpha} F j N O M^{2-\alpha} \\
& F j=\frac{1}{A}\left[\frac{1-\alpha}{\alpha}\right]^{\alpha-1}\left[\frac{P F B}{W}\right]^{\alpha-1} N O M^{2-\alpha} Q j \\
& F j=\frac{1}{A}\left[\frac{1-\alpha}{\alpha}\right]^{\alpha-1} P F B{ }^{\alpha-1} W^{1-\alpha} N O M^{2-\alpha} Q j
\end{aligned}
$$

Dari (2.7) ditunjukkan bahwa peningkatan teknologi budidaya (A) dan harga faktor-faktor produksi (PFB) akan mengurangi kuantitas penggunaan faktor-faktor produksi usahatani beras. Sebaliknya peningkatan tingkat upah tenaga kerja $(\mathrm{W})$, varitas faktor-faktor produksi (NOM) dan kontribusi faktor-faktor produksi terhadap produksi $(\alpha)$ akan meningkatkan kuantitas penggunaan faktor-faktor produksi usahatani beras. Asumsi constant returns to scale dari produksi beras menjelaskan bahwa peningkatan produksi beras (Qj) proporsional dengan peningkatan penggunaan faktor-faktor produksi beras $(\mathrm{Fj})$. 
Substitusi (2.7) ke (2.6) akan menghasilkan kondisi optimal penggunaan tenaga kerja, yaitu:

$$
\begin{aligned}
& L j=\frac{1}{A} \frac{(1-\alpha) P F B \times N O M}{\alpha W}\left[\frac{1-\alpha}{\alpha}\right]^{\alpha-1} P F B{ }^{\alpha-1} W^{1-\alpha} N O M^{2-\alpha} Q j \\
& L j=\frac{1}{A}\left[\frac{1-\alpha}{\alpha}\right]^{\alpha-1} P F B^{\alpha} W^{-\alpha} N O M^{3-\alpha} Q j
\end{aligned}
$$

Persamaan (2.8) menjelaskan bahwa peningkatan teknologi budidaya (A) dan tingkat upah tenaga kerja (W) akan menurunkan kuantitas penggunaan tenaga kerja usahatani beras. Sebaliknya peninngkatan kontribusi tenaga kerja terhadap produksi (1- $\alpha)$, harga faktor-faktor produksi (PFB) dan varitas faktor-faktor produksi (NOM) akan meningkatkan kuantitas penggunaan tenaga kerja usahatani beras. Asumsi constant returns to scale dari produksi beras menjelaskan bahwa peningkatan produksi beras (Qj) proporsional dengan peningkatan penggunaan faktor produksi tenaga kerja $(\mathrm{Lj})$ usahatani beras.

Kondisi optimal penggunaan tenaga kerja (Lj)] dan faktor-faktor produksi (Fj) akan menjamin biaya minimal dari usahatani beras. Substitusi (2.7) dan (2.8) ke (2.3) akan menghasilkan kondisi biaya produksi minimum usahatani beras, yaitu:

$$
\begin{array}{r}
C j=F C+\frac{1}{A}\left[\frac{1-\alpha}{\alpha}\right]^{\alpha-1} W^{1-\alpha} P F B{ }^{\alpha} N O M{ }^{3-\alpha} Q j \\
+\frac{1}{A}\left[\frac{1-\alpha}{\alpha}\right]^{\alpha-1} P F B{ }^{\alpha} W^{1-\alpha} N O M{ }^{3-\alpha} Q j \\
C j=F C+\frac{2}{A}\left[\frac{1-\alpha}{\alpha}\right]^{\alpha-1} W^{1-\alpha} P F B{ }^{\alpha} N O M{ }^{3-\alpha} Q j
\end{array}
$$

Dari persamaan (2.9) ditunjukkan bahwa kontribusi biaya tenaga kerja (W) terhadap biaya produksi usahatani beras adalah sebesar (1- $\alpha)$, kontribusi biaya faktor-faktor produksi (PFB) terhadap biaya produksi usahatani beras adalah sebesar $(\alpha)$, dan kontribusi varitas faktor-faktor produksi (NOM) terhadap biaya produksi usahatani beras adalah sebesar $(3-\alpha)$. 
Fungsi biaya produksi usahatani beras menjelaskan bahwa peningkatan produktivitas teknologi budidaya (A) dan rasio kontribusi tenaga kerja dengan kontribusi faktor-faktor produksi $[(1-\alpha) / \alpha]$ akan menurunkan biaya produksi usahatani beras.

Diketahui bahwa tingkat upah (W) dan harga-harga faktor produksi [PFB] tidak dapat dikendalikan oleh petani. Oleh sebab itu usaha untuk meminimalkan biaya produksi usahatani beras adalah melalui peningkatan teknologi budidaya beras sehingga produktivitas lahan (A) semakin tinggi. Peningkatan produktivitas teknologi budidaya secara langsung akan menurunkan biaya produksi usahatani beras.

Dari (2.9) ditunjukkan bahwa efisiensi usahatani beras didindikasikan oleh besar koefisien $(\alpha)$ dan koefisien $(1-\alpha)$. Artinya efisiensi biaya usahatani beras dicapai jika besar koefisien $(0<\alpha<1)$, akan tetapi efisiensi usahatani beras secara keseluruhan apabila usahatani beras tersebut mengahsilkan laba positip keuntungan dalam jangka pendek. Dengan asumsi bahwa harga produk beras, harga teknologi budidaya dan harga faktor-faktor produksi adalah given bagi petani, maka efisiensi usahatani dirumuskan sebagai berikut:

$$
\begin{aligned}
& \text { Penerimaan: } R j=P j \times Q j \quad(2.10 \mathrm{~A}) \\
& \text { Biaya } \quad: C j=F C+\frac{2}{A}\left[\frac{1-\alpha}{\alpha}\right]^{\alpha-1} W^{1-\alpha} P F B{ }^{\alpha} N o M{ }^{3-\alpha} Q j
\end{aligned}
$$

Laba maksimal dicapai apabila penerimaan marginal (Pj) sama dengan biaya marginal $(\partial \mathrm{Cj} / \partial \mathrm{Qj})$, yaitu:

$$
P j=\frac{2}{A}\left[\frac{1-\alpha}{\alpha}\right]^{\alpha-1} W^{1-\alpha} P F B{ }^{\alpha} N O M^{3-\alpha}
$$

Ada dua lagi kemungkinan yang terjadi secara riil pada usahatani beras. Apabila $\quad P j \succ \frac{2}{A}\left[\frac{1-\alpha}{\alpha}\right]^{\alpha-1} W^{1-\alpha} P F B{ }^{\alpha} N O M^{3-\alpha}$ maka petani akan meningkatkan produksi beras dengan cara menambah luas lahan produksi beras, sehingga biaya marginal produksi beras naik mencapai keseimbangan harga pasar produk beras. Sebaliknya apabila 
$P j \prec \frac{2}{A}\left[\frac{1-\alpha}{\alpha}\right]^{\alpha-1} W^{1-\alpha} P F B{ }^{\alpha} N O M{ }^{3-\alpha}$ maka petani akan mengalami kerugian dan akan mengurangi luas lahan produksi beras.

\section{METODE PENELITIAN}

Penentuan sampel dilakukan dengan metode stratified random sampling (Zimund, 1997) berdasarkan luas lahan. Strata luas lahan usahatani beras ditentukan lebih kecil atau sama dengan satu hektar dan lebih besar dari satu hektar.

Dari hasil perhitungan ditentukan bahwa jumlah sampel dengan strata luas lahan kurang atau satu hektar sebanyak 90 kepala keluarga dan jumlah sampel dengan strata lebih dari satu hektar sebanyak 90 kepala keluarga sehingga total sampel adalah sebanyak 180 kepala keluarga yang tersebar dari beberapa kecamatan yang ada di Deli Serdang. Data yang dikumpulkan dalam penelitian ini adalah data primer dengan membagikan Daftar Pertanyaan terhadap seluruh populasi.

\section{Model Analisis dengan Ordinary Least Square}

Metode analisis yang dipergunakann untuk menganalisis faktor-faktor yang mempengaruhi produksi beras digunakan model sebagai berikut :

$$
\mathrm{QB}=\mathrm{QB}[\mathrm{LHN}, \mathrm{BBT}, \mathrm{PPK}, \mathrm{TK}]
$$

Dimana :

$$
\begin{aligned}
& \mathrm{QB}=\text { Jumlah produksi beras }[\mathrm{kg}] \\
& \mathrm{LHN}=\text { Luas lahan }(\mathrm{ha}) \\
& \mathrm{BBT}=\text { Bibit }(\mathrm{kg}) \\
& \mathrm{PPK}=\text { Pupuk }(\mathrm{kg}) \\
& \mathrm{TK}=\text { Tenaga Kerja (Org) }
\end{aligned}
$$

Sedangkan untuk model analisis biaya produksi digunakan model sebagai berikut :

$$
\mathrm{CB}=\mathrm{CB}[\mathrm{PFB}, \mathrm{W}, \mathrm{QB}]
$$

Dimana: $\mathrm{CB}=$ Total biaya produksi usahatani beras $[\mathrm{Rp}]$

$\mathrm{PFB}=$ harga rata-rata faktor-faktor produksi, yaitu jumlah biaya lahan, bibit, pupuk, dan obat-obatan dibagi 3 
$\mathrm{W}=\quad$ harga atau upah rata-rata tenaga kerja, yaitu jumlah biaya tenaga kerja dibagi TK [Rp / jam]

Kedua model tersebut digunakan model Cobb Douglas dan dijabarkan lebih lanjut dalam model analisis ekonometrik sebagai berikut :

$$
\begin{aligned}
& L N Q B=\beta_{0}+\beta_{1} L N L H N+\beta_{2} L N B B T+\beta_{3} L N P P K+\beta_{4} L N T K+\varepsilon_{T} \\
& L N C B=\delta_{0}+\delta_{1} L N P F B+\delta_{2} L N W+\delta_{3} L N Q B+e_{t}
\end{aligned}
$$

Sedangkan untuk melihat bagaimana tingkat efisiensi beras digunakan model sebagai berikut :

1) Usahatani beras dikatakan efisien jika $P \geq \partial C B / \partial Q B$,

2) Usahatani beras dikatakan tidak efisien jika $\mathrm{P}<\partial \mathrm{CB} / \partial \mathrm{QB}$.

\section{HASIL DAN PEMBAHASAN}

Hasil penelitian menunjukkan hanya 3 jenis faktor-faktor produksi yang digunakan oleh petani beras di luar tenaga kerja, yaitu lahan, bibit dan pupuk. Pada Tabel 1 ditunjukkan variasi penggunaan lahan [LHN], bibit [BBT], pupuk [PPK], tenaga kerja untuk pengolahan lahan [LPE], tenaga kerja penanaman dan perawatan [LPP] dan tenaga kerja untuk panen [LPA].

Tabel 1. Nilai rata-rata dan Varians Penggunaan Faktor Produksi

\begin{tabular}{ccccccc}
\hline Variabel & N & Rata-rata & ST. DEV & VARIANCE & MINIMUM & MAXIMUM \\
\hline LHN & 190 & 1.8268 & 0.5645 & 0.11626 & 0.2 & 2.2 \\
BBT & 190 & 14.785 & 7.1376 & 5.6895 & 3.5 & 63 \\
PPK & 190 & 443.27 & 152.17 & 22142 & 101 & 710 \\
TK & 190 & 4.9557 & 1.6543 & 4.6591 & 1.5 & 4.6 \\
\hline
\end{tabular}

Sumber : Hasil pengolahan Data

Tabel 2. Nilai rata-rata dan varians faktor produksi setara lahan dan tenaga kerja

\begin{tabular}{lcrrrrr}
\hline Variabel & N & Rata-rata & ST. DEV & VARIANCE & MINIMUM & MAXIMUM \\
\hline PFB & 190 & 63311 & 2463.2 & 1.20029 & 4434 & 28811 \\
W & 190 & 3458.4 & 798.64 & 8.080292 & 1543 & 6136 \\
QB & 190 & 5525.7 & 2071.6 & 9.22226 & 1832 & 14400 \\
\hline
\end{tabular}

Sumber : Hasil Pengolahan Data 
Biaya produksi usaha tani beras adalah penjumlahan biaya sewa lahan, bibit, pupuk, tenaga kerja untuk pengolahan lahan, tenaga kerja untuk penanaman dan perawatan, dan biaya tenaga kerja untuk panen. Biaya produksi usahatani beras merupakan biaya opportunitas karena petani belum tentu menyewa lahan dan menyewa tenaga kerja untuk mengelola usahatani beras. Penerimaan atau revenue usahatani beras adalah jumlah produksi dikali harga jual petani beras. Laba usahatani beras adalah penerimaan dikurang biaya opportunitas produksi, sehingga laba usahatani beras tersebut merupakan laba ekonomis.

\section{Hasil Estimasi Model}

Model produksi, penggunaan faktor produksi, tenaga kerja dan biaya opportunitas produksi, yang dirumuskan dalam bentuk tipe CobbDouglas. Secara parsial, semua koefisien produksi [QB] yaitu luas lahan (LHN), Pupuk (PPK) dan Tenaga Kerja (TK) signifikan pada tingkat $\alpha=1$ persen kecuali bibit (BBT). Secara global juga semua koefisien signifikan pada tingkat $\alpha=1$ persen karena koefisien determinasi [ $\left.R^{2}\right]$ cukup tinggi.

Hasil Pengolahan Data dengan mempergunakan program Eviews ditunjukkan dalam tabel berikut:

Tabel 3. Hasil Estima Fungsi Produksi

\begin{tabular}{|l|l|l|l|l|}
\hline Dependent Variable: LNQB \\
\hline Method: Least Squares & Coefficient & Std. Error & t-Statistic & Prob. \\
\hline Variable & 7.25180 & 0.3455 & 20.9900 & 0.0000 \\
\hline C & 0.50522 & 0.0912 & 5.5420 & 0.0000 \\
\hline LNLHN & 0.03331 & 0.0598 & 0.5568 & 0.5780 \\
\hline LNBBT & 0.18159 & 0.0501 & 3.6280 & 0.0000 \\
\hline LNPPK & 0.26952 & 0.0423 & 6.3720 & 0.0000 \\
\hline LNTK & 0.973170 & F-statistic & 378.1423 \\
\hline R-squared & 1.515922 & Prob(F-statistic) & 0.000000 \\
\hline Durbin-Watson stat &
\end{tabular}

Sumber : Hasil Pengolahan Data dengan eviews

Koefisien elastisitas produksi [QB] terhadap penggunaan faktor produksi lahan, bibit, pupuk dan penggunaan tenaga kerja masing-masing sebesar 0.50522 untuk lahan, 0.03331 untuk bibit, 0.18159 untuk pupuk dan 0.26952 untuk tenaga kerja sesuai dengan ekspektasi teori.

Secara partial seluruh variabel yang diamati ternyata signifikant pada tingkat $\alpha=1 \%$ dengan derajat tingkat kepercayaan 99\%, kecuali untuk QE Journal | Vol.03 - No.04 December 2014 - 240 
variabel bibit yang tidak signifikan yang dapat dilihat dari $t$ hitung ataupun dari P-Value. Demikian juga secara simultan faktor produksi secara nyata ditentukan oleh keempat faktor tersebut, yaitu lahan, bibit, pupuk, dan tenaga kerja, yang ditunjukkan oleh nilai Uji F.

Koefisien determinan sebesar 0, 9731 menunjukkan bahwa variabel produksi beras dapat dijelaskan oleh faktor lahan, bibit, pupuk dan tenaga kerja sebbesar 97,31 persen sedangkan sisanya sebesar 2.69 persen dijelaskan oleh faktor lainnya yang tidak dimaksukkan ke dalam model analisis.

Dengan demikian persamaan untuk fungsi produksi beras dapat dibentuk sebagai berikut :

$L N Q B=7.25180+0.50522 L N L H N+0.03331 L N B B T+0.18159 L N P P K+0.26952 L N T K$

$$
(20.9900) \quad(5.5420) \quad(0.5668) \quad(3.6280) \quad(6.3720)
$$

atau

$$
\mathrm{QB}=\exp [7.25180] \mathrm{LHN}^{0.50522} \mathrm{BBT}^{0.03331} \mathrm{PPK}^{0.18159} \mathrm{TK}^{0.26952}
$$

Model total biaya produksi usahatani beras [Rp] (CB) ditentukan oleh harga rata-rata faktor-faktor produksi, yaitu jumlah biaya lahan, bibit, pupuk, dan obat-obatan dibagi 3 (PFB) dan harga atau upah rata-rata tenaga kerja, yaitu jumlah biaya tenaga kerja dibagi TK [Rp / jam] (W) yang dirumuskan dalam bentuk tipe Cobb Douglas. Secara parsial semua koefisien total biaya produksi (CB) yaitu PFB dan $W$ signifikan pada tingkat $\alpha=1$.

Secara global juga semua koefisien signifikan pada tingkat $\alpha=1$ persen karena koefisien determinasi $\left[\mathrm{R}^{2}\right]$ cukup tinggi. Hasil Pengolahan Data dengan mempergunakan program Eviws ditunjukkan dalam tabel berikut:

Tabel 4. Hasil Estimasi Fungsi Biaya Produksi

\begin{tabular}{|l|l|l|l|l|}
\hline Dependent Variable: LNCB \\
\hline Method: Least Squares \\
\hline Variable & Coefficient & Std. Error & t-Statistic & Prob. \\
\hline LNPFB & 0.31274 & 0.0230 & 13.63 & 0.0000 \\
\hline LNW & 0.36592 & 0.0293 & 12.51 & 0.0000 \\
\hline LNQB & 0.97204 & 0.0146 & 66.62 & 0.0000 \\
\hline R-squared & 0.9708 & F-statistic & 1370.024 \\
\hline Durbin-Watson stat & 1.6688 & Prob(F-statistic) & 0.000000 \\
\hline
\end{tabular}

QE Journal |Vol.03 - No.04 December 2014 - 241 
Koefisien elastisitas biaya produksi [CB] terhadap faktor harga rata-rata faktor-faktor produksi, yaitu jumlah biaya lahan, bibit, pupuk, dan obatobatan dibagi 3 (PFB) sebesar 3.1274 dan harga atau upah rata-rata tenaga kerja, yaitu jumlah biaya tenaga kerja dibagi TK [Rp / jam] (WAG) sebesar 0.36592 serta faktor produksi sebesar 0.97204 sesuai dengan ekspektasi teori.

Secara partial seluruh variabel yang diamati ternyata signifikant pada tingkat $\alpha=1 \%$ dengan derajat tingkat kepercayaan 99\% yang dapat dilihat dari t hitung ataupun dari P-Value. Demikian juga secara simultan faktor biaya produksi secara nyata ditentukan oleh ketiga faktor tersebut yang ditunjukkan oleh nilai Uji F.

Koefisien determinan sebesar 0, 9708 menunjukkan bahwa variabel biaya produksi beras dapat dijelaskan oleh faktor jumlah biaya lahan, bibit, pupuk, dan obat-obatan dibagi 3 (PFB) dan harga atau upah rata-rata tenaga kerja, yaitu jumlah biaya tenaga kerja dibagi TK [Rp / jam] (W) serta faktor produksi (QB) sebesar 97.08 persen sedangkan sisanya sebesar 2,92 persen dijelaskan oleh faktor lainnya yang tidak masuk dalam model.

Dengan demikian persamaan untuk fungsi biaya produksi beras dapat dibentuk sebagai berikut :

$$
L N C B=3.1274 L N P F B+0.36592 L N W+0.97204 L N Q B+e_{t}
$$

atau

$$
\mathrm{CB}=\mathrm{PFB}^{3.1274} \mathrm{~W}^{0.36592} \mathrm{QB}^{0.97204}
$$

\section{Analisis Efisiensi ekonomi Usahatani Beras}

Analisis efisiensi ekonomi dari usahatani beras dicapai pada kondisi biaya marginal sama lebih kecil atau sama dengan harga jual beras. Dalam hal ini diasumsikan pasar komoditas beras adalah pasar persaingan, sehingga laba maksimal dari usahatani beras diperoleh pada kondisi $\mathrm{P} \geq \mathrm{MCUJ}$. Dari model biaya opportunitas produksi usahatani beras diperoleh biaya marginal, yaitu:

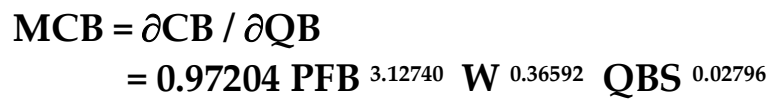


Dari hasil perhitungan biaya marginal produksi usahatani beras di Deli Serdang adalah:

$$
\begin{aligned}
\text { MCB } & =0.97204 \text { PFB }{ }^{3.12740} \mathrm{~W}^{0.36592} \text { QBS }^{0.02796} \\
& =0.97204[10.861]^{3.12740}[8.2790]^{0.36592}[8.6756]^{0.02796} \\
& =\text { Rp 3.885,12 per kilogram }
\end{aligned}
$$

Hasil perhitungan di atas menjelaskan bahwa biaya marginal produksi beras [Rp 3.885,12 per kilogram] jauh lebih rendah dari harga jual beras [Rp 5000 per kilogram]. Dengan kata lain usahatani beras di Kabupaten Deli Serdang efisien. Biaya marginal produksi yang lebih rendah dari harga jual beras menjelaskan bahwa potensi skala ekonomis masih dapat dieksploitasi.

\section{SIMPULAN DAN SARAN}

\section{Simpulan}

Analisis efisiensi ekonomis usahatani beras di Kabupaten Deli Serdang, hasil penelitian adalah sifat-sifat model produksi, penggunaan faktorfaktor produksi dan biaya opportunitas produksi adalah decreasing returns to scale atau decreasing cost industries, dimana Kontribusi biaya faktor-faktor produksi, yaitu lahan, bibit dan pupuk serta tenaga kerja terhadap biaya opportunitas produksi masing-masing 31,27 persen dan 36.59 persen. Sedangkan kontribusi produksi terhadap biaya opportunitas produksi adalah sebesar 97.20 persen. Skala ekonomis usahatani beras menjelaskan bahwa biaya rata-rata per unit produksi beras cenderung turun sejalan dengan peningkatan produksi beras.

Analisis efisiensi ekonomi dari usahatani beras ditunjukkan oleh kondisi biaya marginal produksi lebih kecil dari harga jual beras, dimana biaya marginal produksi beras per kilogram sebesar Rp 3.885,12 dengan harga jual produksi beras sebesar Rp 5000 per kilogram.

\section{Saran}

Dari kontribusi lahan, bibit dan pupuk serta tenaga kerja terhadap produksi usahatani beras dijelaskan bahwa peningkatan produksi beras dapat dilakukan dengan meningkatkan penggunaan lahan, bibit, pupuk dan tenaga kerja. 
Peningkatan penggunaan lahan, bibit, pupuk dan tenaga kerja akan mengakibatkan peningkatan produksi atau penerimaan lebih tinggi dari peningkatan biaya opportunitas produksi, sehingga tingkat keuntungan petani beras meningkat.

Peningkatan varitas faktor-faktor produksi usahatani beras juga akan mengakibatkan peningkatan produksi atau penerimaan lebih tinggi dari peningkatan biaya opportunitas produksi, sehingga tingkat keuntungan atau laba usahatani beras semakin tinggi.

\section{DAFTAR PUSTAKA}

Chiang, A. C. and K. Wainwright. 2005. Fundamental Methods of Mathematical Economics. Fourth Edition. Indonesia: McGrwa-Hill International Edition.

Dixit, A. K. and J. E. Stiglitz. 1977. "Monopolistic Competition and Optimum Product Diversity". American Economic Review 67: 297-308.

Ethier, W. J. 1982. "National and International Returns to Scale in the Modern Theory of International Trade". American Economic Review 72: 389-405.

Gujarati, D. N. 2003. Basic Econometrics. Fourth Edition. Singapore: McGraw-Hill International Edition.

Judge, G. G. et. al. 1988. Introduction to the Theory and Practise of Econometrics. $2^{\text {nd }}$. ed. New York: John Wiley \& Son Inc.

Mubyarto. 1989. Pengantar Ekonomi Pertanian; Jakarta: LP3ES.

Pindyck, R. S. and D. L. Rubinfeld. 1995. Microeconomics. Third Edition. New Jersey: Prentice-Hall International, Inc.

Rahardi, S. Wahyuni dan E. M. Nurcahyo. 2000. Pengantar Agribisnis. Jakarta: Penebar Swadaya.

Romer, P. M. 1986. "Increasing Returns and Long-Run Growth". Journal of Political Economy 94: 1002-1037.

Romer, P. M. 1990. "Endogenous Technological Change". Journal of Political Economy 98: S71-S102.

Ruskadin. 2003. Prospek Usahatani Beras Sebagai Tanaman Sela di Antara Tegakan Kelapa. Buletin Teknik Pertanian (8): 2. 
Ruskadin. 2005. Teknik Pemupukan Buatan dan Kompos pada Tanaman Sela Beras di antara Kelapa. Buletin Teknik Pertanian (10): 2.

Sarasutha, I. G. P. 2002. Kinerja Usahatani dan Pemasaran Beras di Sentra Produksi. Jurnal Litbang Pertanian (21): 2.

Soekartawati. 1994. Teori Ekonomi Produksi dengan Pokok Bahasan Analisis Fungsi Produksi Cobb-Douglas. Jakarta: Raja Grafindo Persada.

Soekartawati. 1999. Agribisnis: Teori dan Aplikasinya. Jakarta: Raja Grafindo Persada.

Spence, M. 1976. "Products Selection, Fixed Cost, and Monopolistic Competition". Review of Economic Studies 43: 217-235.

Subandi, Zubachtirodin dan A. Nazamuddin. 2005. Produksi Beras Melalui Pendekatan Pengelolaan Sumber Data dan Tanaman Terpadu pada Lahan Kering Masam. Bogor: Puslitbang Tanaman Pangan.

Tohir. 1991. Seuntai Pengetahuan Usahatani. Jakarta: Rineka Cipta.

Varian, H. R. 1993. Intermediate Microeconomics: A Modern Approach. Third Edition. New York: W. W. Norton \& Company.

Zikmund, W. G. 1997. Business Research Methods. Fifth Edition. USA: The Dryden Press Harcourt Brace College Publishers. 